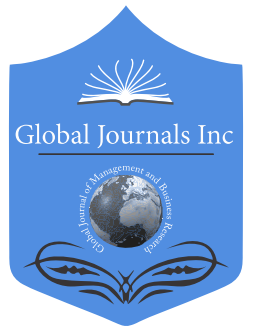

GLOBAL JOURNAL OF MANAGEMENT AND BUSINESS RESEARCH: A ADMINISTRATION AND MANAGEMENT

Volume 20 Issue 17 Version 1.0 Year 2020

Type: Double Blind Peer Reviewed International Research Journal

\title{
An Exploration of Unethical Behavior Attitude of Tertiary Level Students of Bangladesh
}

\author{
By Sirajul Arefeen, Muhammad Khairi Bin Mohyuddin \& \\ Mohammad Aktaruzzaman Khan
}

Abstract- In this competitive world highly skilled manpower is considered to play key role in developing a nation. On the other hand, highly educated people are blamed for recent business and financial scandals. Moreover, studies established that pupils who deceive in their student life are found to be engaged in immoral workplace conduct. The Student today is the future leader of the country. Hence, the combination of quality with morality is emphasized in the universities of in many developed counties like the USA, China, and moral education is being imparted at all stages of academic organizations and training centers from kindergarten to national academia. Therefore, the goal of the research is to explore the origins of the unethical behavior of University students of Bangladesh and recommend the means to improve the situation.

Keywords: students' unethical behavior; tertiary level education; unethical workplace behavior.

GJMBR-A Classification: JEL Code: M19

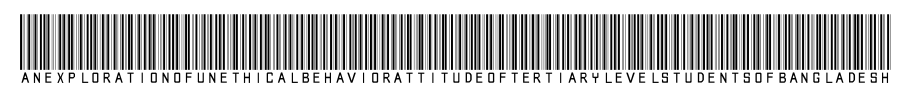

Strictly as per the compliance and regulations of:

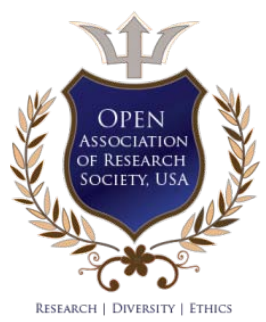

(C) 2020. Sirajul Arefeen, Muhammad K hairi Bin Mohyuddin \& Mohammad Aktaruzzaman Khan. This is a research/review paper, distributed under the terms of the Creative Commons Attribution-Noncommercial 3.0 Unported License http://creative commons.org/licenses/by-nc/3.0/), permitting all non-commercial use, distribution, and reproduction in any medium, provided the original work is properly cited. 


\title{
An Exploration of Unethical Behavior Attitude of Tertiary Level Students of Bangladesh
}

\author{
Sirajul Arefeen ${ }^{\alpha}$, Muhammad Khairi Bin Mohyuddin ${ }^{\sigma}$ \& Mohammad Aktaruzzaman Khan ${ }^{\circ}$
}

\begin{abstract}
In this competitive world highly skilled manpower is considered to play key role in developing a nation. On the other hand, highly educated people are blamed for recent business and financial scandals. Moreover, studies established that pupils who deceive in their student life are found to be engaged in immoral workplace conduct. The Student today is the future leader of the country. Hence, the combination of quality with morality is emphasized in the universities of in many developed counties like the USA, China, and moral education is being imparted at all stages of academic organizations and training centers from kindergarten to national academia. Therefore, the goal of the research is to explore the origins of the unethical behavior of University students of Bangladesh and recommend the means to improve the situation.
\end{abstract}

Keywords: students' unethical behavior; tertiary level education; unethical workplace behavior.

\section{INTRODUCTION}

(eved he growth of the country and civilization is exceedingly conditional to the quality of the education of the country. Therefore, advancedlevel education is for producing able, conversant and visionary citizens for shouldering several innovative obligations. In this extremely competitive global society, the need of up-to-date knowledge and expertise is increasing rapidly. Specially, higher education plays the vital role for the progress of emerging economy and the society (UGC, 2006). The necessity of remarkably competent and experienced persons is recognized for sustainable development and poverty mitigation from the preceding era. A student today will be the future leader of the country. Hence, educational institutions contribute to society by providing professionals in every sphere of society as need be, like doctors, engineers, academics, intellectuals, etc. By which integrated development of a country and personnel management as well as improvement is accomplished. It is only possible by the efforts of skilled personnel of the nation. Through research and extensive investigation,

Author a: PhD fellow, University Sains Islam Malaysia (USIM), Malaysia International Islamic University Chittagong (IIUC), Bangladesh.

e-mail: sarefeen1973@yahoo.com

Author $\sigma$ : Faculty of Leadership and Management, University Sains Islam Malaysia (USIM), Malaysia.

Author $\mathrm{\rho}$ : Department of Business Administration, International Islamic University Chittagong (IIUC), Bangladesh. educational and training institutions also provide up-todate and well equipped general and technical equipments for every sector of the state as per the requirements of the research and development division of the country and the corporations (UGC, 2005).

Higher education institutes are established to introduce new concepts, methods, techniques, and principles through experimentations, investigations and other study procedures. These are established to generate highly trained and proficient manpower with the expected level of morality and know-how to work for the society and the nation as a whole (Momen \& Baniamin, 2010).

On the other hand, in the last few decades, many commercial and financial outrages have drawn the public attention particularly the duties of the responsible persons of the community. So, morality has been considered as the key factor in the business arena as for planned policy making. Otherwise, it will lead to financial loss, and the reputation of the company may affect negatively. Immoral performance of the companies was highly accountable for the current financial disasters (Sedmak \& Nastav, 2010).

The reputation of a nation to a great extent depends on its educated and talented citizens. In other words, the products or services offered by an organization, especially a university is the prime to reflect the quality of its future products, the students on which the nation has been looking to.

In current ages, many reputed business enterprises like Tyco, WorldCom, Enron, and HewlettPackard are blamed to be involved in immoral business practices. These indecencies appear to be increased day by day and need to be addressed immediately. Academic institutions are not free from these types of unethical practices, too (Raguz \& Matic, 2015).

The economic growth and overall achievement of China are commendable. But moral degradation of the mass people of China is a great concern for the country (Shafer et al., 2007). Therefore, moral education is being taught at every level of academic institutions from kindergarten to national academia. (Bettignies \& Tan, 2007).

It is reported that $50 \%$ of fresh teachers in the USA are resigning from their jobs before being served 
for five years (Lambert \& McCarthy, 2006). It is also affirmed that nearly $25 \%$ of them are leaving their jobs due to students' misconduct or immoral behavior (Ingersoll, 2003). Therefore, it will not be shocking if academics relate students' unethical behavior to teacher emotional exhaustion (Abel \& Sewell, 1999; Betoret, 2009; Gelman, 2008; Kokkinos, 2007).

Several studies endorse the Josephson (2012) report that almost $50 \%$ students confess to a certain forms of unfair means in the examinations. As per the Report Card of American Youth conducted by the Institute of Josephson in 2012, more than 50\% students over 23,000 admitted to adopt unfair means in the examinations in the previous year. Cheating in the tests spoils the fundamental purpose of the educational institute, misrepresents the reliability of grades awarded to the students as a level of subject knowledge. This grade may not speak about the factual aptitude of the student. (Fendler \& Godbey, 2016).

Asian countries are not free from this extensive cheating incidence like as Taiwan. As per the study of 2,068 college students of Taiwan cheating rate was reported $61.7 \%$ (Lin \& Wen, 2007). It is important to comment that unethical academic behavior misleads the main purpose of the educational institutes to impart and create knowledge, damages the honesty in awarding proper grading method, and weakens total societal justice (Whitley \& Keith-Spiegel, 2002).

As per previous studies, students who violate school regulations during their student life are found to be involved in immoral workplace activities (Harding et al., 2004; Nonis \& Swift, 2001). Hence it may be treated as rounded crisis. Felton and Sims (2005, p.377) have identified that past commerce students have remained at the "focus of the corporate outrages of the previous years". Weisul and Merritt (2002, p.8) have emphasized addressing the youths of the country "morality should be inculcated to the mind of the young society, transform them as the asset and strength of the country rather than the criminals of the future".

It is inscribed in the main entrance of the University of South Africa that it is not necessary to attack by missiles or nuclear weapons to destroy a nation, rather allow the students of the nation to cheat in the exam.

According to Anitsal and Elmore (2009), involvement with duplicitous behavior in student life may guide him to immoral conduct at the workplace. In consultation with the above literature, the author found no such prior research investigating this topic in Bangladesh, which is urgently felt now.

\section{il. Methodology}

Systematic data collecting and analyzing process have been followed in this investigation. It is stated by Tranfield, Denyer, and Smart (2003) that the objective of the literature review is to determine the gap in the prevailing literature. According to Seuring and Muller (2008), the literature review categorizes existing literature on the basis of the main points. Saunders (2011) opined that perfect review process of literature should initiate with ascertaining suitable keywords by which researchers finds their necessary articles from the databases. As Scopus and Web of Science database were considered as dependable and representative by the former researchers (Fahimnia, Sarkis, and Davarzani, 2015; Seuring \& Müller, 2008; Tseng et al., 2019, Apriliyanti \& Alon, 2017; Tian et al., 2018). Therefore, both databases were selected for the study.

This study followed two well established theories to describe the ethical behavior attitude of the university students: these are Kohlberg's Theory on Moral Development (Kohlberg, 1976) and of Planned Behavior Theory (Ajzen, 1991). This article aims to find out the prime causes of the unethical behavior of the tertiary level of students in Bangladesh and to recommend possible solutions to overcome the situation. The following questions are addressed in this study: What are the causes of unethical behavior of tertiary level students? Is there relation between students unethical behavior and unethical workplace behavior?

\section{a) Review Method}

The Web of Science and Scopus databases are considered as the main sources for articles. The study used three terms, students' unethical behavior-tertiary level education, and unethical workplace behavior as keywords to explore research articles. On the mentioned databases, articles are categorized into many kinds. The study chooses two categories Educational Research, and Ethics where articles were searched from these two disciplines only.

Articles are then taken out under the disciplines, which contain unethical behavior, tertiary level students, and unethical workplace behavior terms. Altogether only 65 articles were found on the Web of Science database. Nevertheless, after going through all articles, 54 are chosen for systematic review and the remaining 11 articles were not studied for their unsuitability. To catch additional articles, Scopus databases also explored and found additional 5 articles. Finally, 59 research articles were selected for this study.

On the basis of methodologies, research articles are classified into qualitative, quantitative, conceptual, and mixed-mode categories. Conceptual articles emphases basically on theory development. It does not present and analyzes data to test a theory (Yadav, 2010).

\section{ili. ReView of Literature}

The very term 'ethics' develops after the Greek term 'ethos' sense 'character' or 'tradition'. Ethics can 
be designated formally as "the discipline dealing with what is good and bad concerning moral duty and obligation" Merriam-Webster Dictionary (2015). Ethics may be outlined as "the interpretation of moral philosophies or principles that govern whether activities are correct or incorrect, and consequences are decent or corrupt (McShane \& Glinow, 2008).

Ethics may also be defined as "a set of principles and standards by which one's actions are judged as right or wrong, honest or dishonest, fair or not fair" (Ryan \& Bisson, 2011; Weygandt et al., 2003, p. 8 ). Desplaces, Beauvais, Melchar, and Bosco (2007) stated that appropriate moral teaching can motivate the aptitude of a person to take essential moral decisions in their workplace.

Numerous components lead and guide a university student towards practicing academic ethics. The following are the few elements of many which affect in the conduct of the university student; this area; institutional values, personal inclinations and concepts of ethics, outer factors, and pressure of associates (Saini, 2012).

\section{a) Ethical and unethical behavior}

The conduct of a person is the manifestation of his ethical belief. It speaks about the individual's way of dealings with others. The conduct of a person is well biased by societal culture and standard, family rules and norms, religion, peer-pressure, and surroundings (Sauser, 2005).

Arens et al. (2008) stated that morality works as a paste to retain the society under the same umbrella and thus, every member of the society is ethically benefitted. Therefore, society should take the responsibility to promote value and ethics to the young generation of the community who will be future professionals. Lying, fabricating, and deceiving are the root of all sorts of immoral behavior (Nga \& Lum, 2013).

Aquino and Reed (2002: 1424) termed moral character as "a self-conception organized around a set of moral traits." They listed nine moral character themes (supportive, honest, caring, diligent, compassionate, kind, just, sociable, and generous) followed by a sequence of messages.

Prophet of Islam Mohammad (saw) says: "You cannot treat people by means of your wealth; hence, you should treat them by means of your moral conduct" (Al-Bukhari, Al-Muslim). "You should restrain yourself from doing wrong to people because it (serves as) charity which you bestow upon yourself" (Al-Bukhari and Al-Muslim). "Do not belittle any good deed, even meeting your brother with a cheerful face"

"Every good deed is a charity" (Al-Bukhari). (Muslim).

Almighty Allah (swt) says "You are the best of the nations raised for (the benefit of) men; you enjoin what is right and forbid the wrong and believe in God, and if the followers of the Book had believed it would have been better for them; of them (some) are believers and most of them are transgressors." (The Holy Quran: 3:110)

Prophet Mohammad (saw) says "Give up what is doubtful to you for that which is not doubtful; for truth is peace of mind and falsehood is doubt". (At-Tirmidhi). ....... 'Hazrat Abd Allah Ibn 'Amr stated, "There are four characteristics that, if you possess them, will prevent you from being affected if you are deprived of certain worldly benefits. They are good character, chaste outlook, honesty, and trustworthiness." (A-Bukhari)

How a person treats his action and conduct, whether moral or immoral and the degree of measurement of the behavior is the ethical judgment as explained by (Sparks and Pan, 2010). Consequently, the ethical decision governs the behavior and way of enactment of a person.

\section{b) Foundation of behavior (ethical/unethical)}

Learning is a continuous process. Man does not learn from the womb of his/her mother. From boyhood, he is very much curious. He follows, observes his surroundings. As per Kohlberg Moral Development Theory, Theory of Planned Behavior, and existing literature, human being learn ethics from the following sources:
i. Parents and family
ii. Society
iii. Teachers and educational institutions
iv. Religious institutions (mosque, madrasha, temple, church, etc.)
v. Friends (clubs, social network) and
vi. Media (Electronic, social, and print)
vii. Course content

\section{c) Higher Education in Bangladesh: The Present Scenario}

Since liberation in 1971, the education system of Bangladesh has experienced many amendments" (Middlehurst \& Woodfield, 2004:3). Its education system is three-tiered and highly subsidized. There are four levels and stages in the education structure of Bangladesh; levels are primary, secondary, higher secondary, and tertiary education level education. Educational instructions are termed as school, college, madrasha and University. Islamic religious education is imparted in the madras has. There are public and private educational institutions at all levels of education. A proper expected educational environment does not prevail in Bangladesh. Universities of Bangladesh are not running as per University Act, all public universities except Jahangirn agar University are running without elected Vice-Chancellor. Many irregularities are in 
teachers' recruitment, The Daily Prothom

Alo (28/05/2013). Many more problems are as follows:

\section{i. Leak out of Question Paper \\ Leaking out of question paper has become a} common phenomenon in Bangladesh since independence (i. e, 1972) except during 2001 - 2006. According to the statement of The Daily Naya Diganhta (23/11/2013), The Daily Dinkal (18/02/17), The Daily Manab Zamin (19/02/17) published reports on leaking out of question paper.

\section{ii. Cheating in the examination}

The Daily Dinkal (18/02/17), The Daily Prothom Alo, sub editorial (24/05/2014) reported that a mere higher grade or GPA would not play any role in the educational development of the country until cheating in the exam is not strictly controlled.

\section{iii. Student politic-Campus Violence}

Campus violence is a common incident in almost all public Universities and Colleges of Bangladesh. Reported by the Daily Naya Diganta (09/01/2014), The Daily Jugantor (25/01/17), and (18.02.2017), The Daily Ittefaq (18/02/17).

\section{iv. Recruitment of teachers on political consideration}

The Daily Prothom Alo (06/07/13), The Daily Naya Diganta (18/04/2014), The Daily Dinkal \& The Daily Ittefaq (18/02/17) cited that teachers are recruited in the universities of Bangladesh with political consideration. They blamed that less qualified teachers were recruited on political consideration.

\section{v. Complain about the teachers of the Public University Teachers}

Keeping aside their prime academic responsibilities and research, teachers of public universities are involved in politics for their material gains. As per report of The Daily Naya Diganta (14/10/2014), The Daily Prothom Alo on 25/04/2014, Prof. Abdul Mannan, Chairman of UGC, said that teachers were not found in the class room now. There is a serious lack of accountability of the University teachers. Therefore, students are deprived of proper education and guidance. Hence, the total education system is damaging day by day.

\section{Corruption}

Bangladesh is a developing country. University and higher education institutions are growing day by day. The rate of education is also increasing noticeably. But corruption is not decreasing in Bangladesh. Unfortunately, Bangladesh is in the low-ranked positioned in the list of countries of corruption by the world community. The score of Bangladesh was 26 out of 100 and positioned $14^{\text {th }}$ from the lowermost and ranked $146^{\text {th }}$ from the uppermost among 180 countries in the world as per report of Transparency International's (TI), 2019. Transparency International Bangladesh (TIB) revealed in its graft perception index at a meet the press session in Dhaka held in January 23, 2020. While Bangladesh scored a meager 26, was positioned in 13th in 2018 from the bottom, down from 17th in 2017. Therefore, it is proved that higher education does not play any noteworthy role in resisting corruption in Bangladesh.

\section{a) Causes of poor ethical practice in Bangladesh}

As we talked, intentions of immoral behavior are lured by hedonism and selfishness. It has become a burning question for Bangladesh. As far as ethical behavior concern, we are far behind from the expected level. Following reasons may be cited for the crisis:

i. Moral behavior is given less importance at family level. Money making or career building is considered as the main objective of their children.

ii. Value free society or poor ethical practice in society.

iii. Ethics free education.

iv. Selfishness.

V. Poor practice of religious rules.

vi. Following trends of the life style of developed countries,

b) Types of unethical behavior of University Students

University students repeatedly violate the ethical codes of the institutions. To define violation of academic decency, the words 'academic corruption,' 'academic dishonesty,' and academic misconduct' are used alternately, 'dishonesty' denotes an intangible thought where 'cheating' and 'misconduct' denotes behavior. On the other hand, 'academic cheating' is usually used for tests and unethical behaviors are termed 'academic misconduct' (McCrink, 2010).

Violation of university rules refers to undesirable activities listed by the institutions, such as unlawful use of academic belongings and misbehavior with teachers (Zopiatis \& Krambia-Kapardis, 2008).

West et al. (2004) claimed that cheating is responsible for abuse and harm many rules and customs but most importantly, justice. By cheating, a student enjoys unjustified benefit over his classmates that he does not deserve and it happens mainly for selfcenteredness, and attainment inspiration.

Siegfried (2004) opined that the propensity of students to (a) dishonesty, (b) violation of school regulation, (c) copy software or use of computer in an unlawful way, indicates that they are concerned with their benefit and are motivated by self-centeredness.

Among different types of academic corruption, cheating on examinations is considered as a severe and 
immoral form of behavior (Hrabak et al., 2004; Hsiao \& Yang, 2011).

Plagiarism is recognized to cover a big percentage of academic misbehavior. Recently a study was done by the alumni of higher education about their perception on cheating, 19 dishonest conducts were explored, the utmost common practices were itemized as letting other students to copy, duplicating from existing works, repeating articles, and copying (Plagiarism) (Yardley et al., 2009).

The persistent problem of copying and plagiarism are named under many terms like-wise: fraud, faulty quotation, patent encroachment, literary burglary, borrowing, cheating, copying, and pilfering (Marsh, 2007). Irrespective of the difference of term, name, and grade, cheating is illegal and prohibited. Hence, there is no choice to educational institutions to admit it (Fendler \& Godbey, 2016).

Paulhus et al. (2005) stated that academic cheating has become simple and stress-free now. One can have the required information and text from the computers within micro second by using the internet. Therefore, misuse of computers and the internet can also be treated as unethical behavior.

Model

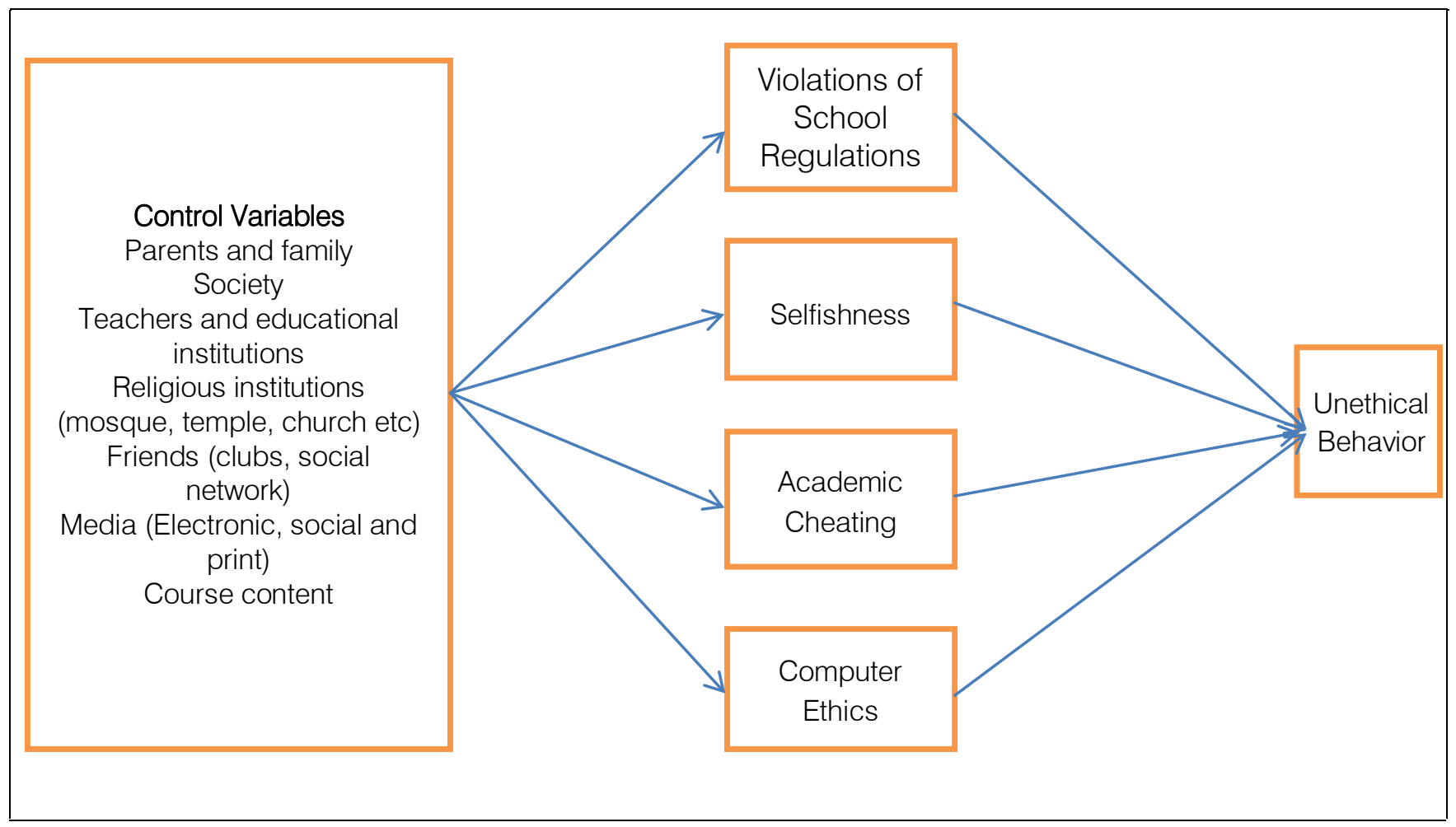

\section{c) Reasons behind adopting unethical means by students}

It appears that involvement with immoral works, and these conducts are accomplished knowingly as accustomed culture in their everyday life. These conducts may be considered as usual in the days to come (Baack et al., 2000; Bernardi et al., 2004 a, b). So, immense importance should be given to detect these immoral practices without wasting time, and needed strategy and program have to be proposed to limit and control them

Jones (2011) attempted to explore the causes behind students' involvement in academic corruption. His study established that $92 \%$ of the learners are involved in academic cheating for attaining better results. Other causes are being occupied in supplementary works, not having enough time to finish homework or coursework for exams; more importantly academic cheating is not considered as a big fault since the maximum student is committing it, and lastly, friends' pressure.

Different variables, mostly neutralizing approaches and extraneous motivation, are grounds for more dishonest and cheating behavior. Information on others' acts of dishonesty and misconduct plays the vital role in enhanced violation of individuals' integrity (Rettinger \& Kramer 2009).

Students really do not know what is plagiarism and the difference between academic and normal writing. The cause behind plagiarism may be the witlessness and lack of knowledge about academic writing (Devlin \& Gray, 2007; lyer, \& Eastman, 2006; Park, 2003). Academic cheating may spread in educational institutions like an epidemic as it is hardly barred and penalized. 
When there is less possibility of being accused and are hardly priced for their academic misdeeds, students are motivated to choose this dishonest behavior (Bennett, 2005; Pickard, 2005; Selwyn, 2008; Sileo \& Sileo 2008; Stephens et al., 2007; Walker, 2010).

Paulhus et al., (2005) paid credits to computers and the internet for students' inclination in cheating as anybody can have required information and writings within a moment with the help of the internet. The internet has now become surpassingly modern mode of copying (Milliron \& Sandoe 2008; Stephens, et al., 2007).

\section{Conclusion and Policy Implication}

As stated by Williams et at., (2014), like the universities of UAE, an honor code needs to be introduced. Every student, teacher, and staff member has to sign to the bond. It is obligatory for everybody to follow the honor code. If students fail to comply with the signed rules will have to face penal action like punishment or expulsion from the university.

In line with Ma, McCabe, \& Liu (2013), knowledge of ethical and unethical behaviors should be imparted to the students first. Then the consequences for several types of unethical academic behaviors should be declared openly, and it is applied regularly. Finally, communication of academic Integrity guidelines needs to be emphasized to all students and inspiring teachers to contribute in teaching academic integrity.

In riposte to emerging trends of ethics, the National Association of State Boards of Accountancy (NASBA, 2005) primarily recommended three topics to address ethics related issues (i.e., principal of ethics, business ethics, and ethics course for accounting). Reflecting on previous studies ethic course has a significant impact on ethical behavior.

Mosalanejad, Dehghani, and Abdolahifard (2014) specified that various philosophers and social scientists have given stress the connection between religion, morals, and technology and stated that religion could be functional to limit the adverse effect of technology.

Conroy and Emerson (2004) and Albaum and Peterson (2006) established by their survey that religiosity is meaningfully interrelated with moral understandings. Religious students were found to behave more rationally and ethically.

Above all, students have a great impact on teachers' attitudes and behavior in their life. Teachers are the role model, guides, and philosophers for the students. Therefore, teachers should also be concerned about dishonesty and well- mannered and behaved in their personal life. The role of faculty members is high in making students familiar with the prime purpose of education and academic decency. Faculty members have to motivate and guide the students to uphold the defined academic behavior as well as the make conscious of the disadvantages and penalties of unanticipated actions.

Even though, it is not that much easy to resolve the issue, a planned means and technique should be set-up to refrain the students form this academic corruption, teachers of the institutions, researchers, guardians, and elites of the societies should shoulder the responsibility and consider it as a burning issue of the country. Faculty members' liability is to make aware students about the consequence of it. Awareness development programs needs to be developed by the researchers. University administration has to introduce ethics courses as university requirement courses apart from the compulsory core courses.

\section{References Références Referencias}

1. Anitsal, I., Anitsal, M., \& Elmore, R. (2009). Academic Dishonesty and Intention to Cheat: A Model on Active versus Passive Academic Dishonesty as Perceived by Business Students. Academy of Educational Leadership Journal, 13(2), 17-26.

2. Abel, M. H., \& Sewell, J. (1999). Stress and burnout in rural and urban secondary school teachers. Journal of Educational Research, 92(5), 287-293.

3. Ajzen, I. (1991). The theory of planned behavior. Organizational Behavior and Human Decision Processes, 50(2), 179-211.

4. Arens, A. A., Elder, R. J., \& Beasley, M. S. (2008). Auditing and assurance services: An integrated approach (12th ed.). New Jersey: Prentice Hall.

5. Apriliyanti, I. D., \& I. Alon. (2017). Bibliometric Analysis of Absorptive Capacity. International Business Review 26 (5): 896-907.

6. Aquino, K., \& Reed, A., II. (2002). The selfimportance of moral identity. Journal of Personality and Social Psychology, 83: 1423-1440.

7. Albaum, G., \& Peterson R. A. (2006). Ethical Attitudes of Future Business Leaders: Do They Vary by Gender and Religiosity. Business \& Society, 45 (300).

8. Bettignies, H. C. D., \& Tan, C. K. (2007). Values and management education in China. International Management Review, 3(1), 17-37.

9. Bloodgood, J., Turnley, W., \& Mudrack, P. (2010). Ethics Instruction and the Perceived Acceptability of Cheating. Journal of Business Ethics, 95(1), 23-37.

10. Betoret, F.D. (2009). Self-efficacy, school resources, job stressors and burnout among Spanish primary and secondary school teachers: A structural equation approach. Educational Psychology, 29 (1), 45-68.

11. Baack, D., Fogliasso, C., \& Harris, J. (2000). The personal impact of ethical decisions: a social penetration theory. Journal of Business Ethics, 24(1), 39-49. 
12. Bernardi, R. A., Giuliano, J. L., Komatsu, E., Potter, B. M., \& Yamamoto, S. (2004). Contrasting the cheating behaviors of college students from the United States and Japan. Global Virtue Ethics Review, 5(4), 5-31.

13. Bennett, R. (2005). Factors associated with student plagiarism in a post-1992 university. Assessment \& Evaluation in Higher Education, 30(2), 137-162.

14. Conroy, S. J. and Emerson, T. L. N. (2004). Business Ethics and Religion: Religiosity as a Predictor of Ethical Awareness among Students. Journal of Business Ethics, 50, 383-396.

15. Desplaces, D., Beauvais, L., Melchar, D., \& Bosco, S. (2007). The Impact of Business Education on Moral Judgment Competence: An Empirical Study. Journal of Business Ethics, 74(1), 73-87.

16. Devlin, M., \& Gray, K. (2007). In their own words: a qualitative study of the reasons Australian university students plagiarize. Higher Education Research and Development, 26(2), 181-198. doi:10.1080/0 7294360701310805.

17. Felton, E.L., \& Sims, R.R. (2005). Teaching business ethics: targeted outputs. Journal of Business Ethics, 60(4), 377-391.

18. Fendler, R. J., and Godbey, J. M. (2016). Cheaters Should Never Win: Eliminating the Benefits of Cheating. J Acad Ethics (2016) 14:71-85, DOI 10.1007/s10805-015-9240-8

19. Fahimnia, B., J. Sarkis, and H. Davarzani. (2015). "Green Supply Chain Management: A Review and Bibliometric Analysis." International Journal of Production Economics 162: 101-114.

20. Gelman, R.B. (2008). Demographic and occupational correlates of stress and burnout among urban school teachers. Hofstra University, United States - New York, Retrieved from http://sea rch.proquest.com/docview/304599382?accountid= 14169

21. Harding, T. S., Carpenter, D. D., Finelli, C. J., \& Passow, H. J. (2004). Does academic dishonesty relate to unethical behavior in professional practice? An exploratory study. Science and Engineering Ethics, 10(2), 311-324.

22. Hrabak, M., Vujaklija, A., Vodopivec, I., Hren, D., Marusic, M., \& Marusic, A. (2004). Academic misconduct among medical students in a post communist country. Medical Education, 38(3), 276285.

23. Ingersoll, R. (2003). Is there really a teacher shortage? Philadelphia, PA: University of Pennsylvania, Consortium for Policy Research in Education.

24. Iyer, R., \& Eastman, J. K. (2006). Academic dishonesty: Are business students different from other college students? Journal of Education for Business, 82(2), 101-110.
25. Josephson Institute (2012). Josephson Institute's 2012 report card on the ethics of American youth. Los Angeles, CA. Retrieved from http://characte rcounts.org/programs/reportcard/2012/index.html.

26. Jones, D. L. R. (2011). Academic dishonesty: are more students cheating? Business Communication Quarterly, 74(2), 141-150.

27. Kokkinos, C. M. (2007). Job stressors, personality and burnout in primary school teachers. British Journal of Educational Psychology, 77(1), 229-243.

28. Kohlberg, L. (1976). 'Moral Stages and Moralization: The Cognitive-development Approach', in T. Lickona (ed.), Moral Development and Behavior (Holt, Rinhart \& Winston, New York), pp. 31-53.

29. Lambert, R. G., \& Mc Carthy, C. J. (2006). Understanding teacher stress in an age of accountability (Eds.). Greenwich, CT: Information Age Publishing.

30. Lin, C. H. S., \& Wen, L. Y. M. (2007). Academic dishonesty in higher education: A nationwide study in Taiwan. Higher Education, 54(1), 85-97.

31. Momen, M., \& Baniamin, H., M., (2010). Higher Education in Bangladesh: Status, Issues and Prospects. Pakistan Journal of Social Sciences (PJSS) Vol. 30, No. 2(December 2010), pp. 293-305

32. Middlehurst, R., \& Woodfield, S. (2004:3). Transitional Report - Case Study Bangladesh (October 2003), Commonwealth of Learning and UNESCO.

33. Merriam-Webster Dictionary. (2015). Retrieved on October 1, 2015. http://www.merriamwebster. com/dictionary/ethics.

34. Mosalanejad, L., Deghani, A., \& Abdolahifard, K. (2014). The students' experience of ethics in online systems. Turkish Online Journal of Distance Education-TOJDE October 2014 ISSN 1302-6488 Volume: 15 Number: 4 Article 13

35. McCrink, A. (2010). Academic misconduct in nursing students: Behaviors, attitudes, rationalizations, and cultural identity. Journal of Nursing Education, 49(11), 653-659. http://dx.doi org/10.3928/01484834-20100831-03

36. McShane and Glinow. (2008). Organizational Behavior 4th Editions. United State: Mc Graw-Hill International Editions.

37. Marsh, B. (2007). Plagiarism, alchemy and remedy in higher education. New York: State University of New York Press.

38. Milliron, V., \& Sandoe, K. (2008). The net generation cheating challenge. Innovate: Journal of Online Education, 4 (7). Retrieved from http://innovateonline.info/pdf/vol4_issue6/The__Net_ Generation_Cheating_Challenge.pdf:

39. Ma, Y., Mccabe, L., D., \& Liu, R. (2013). Students' Academic Cheating in Chinese Universities: Prevalence, Influencing Factors, and Proposed 
Action Journal of Academic Ethics, 11(3).DOI: 10.1 007/s10805-013-9186-7

40. Nga, J. K. H., \& Lum, E.W.S. (2013). An Investigation into Unethical Behavior Intentions Among Undergraduate Students: A Malaysian Study. Journal of Academic Ethics volume, 11, 4571.

41. Nonis, S., \& Swift, C. O. (2001). An examination of the relationship between academic dishonesty and workplace dishonesty: a multi campus investigation. Journal of Education for Business, 69-76.

42. National Association of State Boards of Accountancy (NASBA) (2005). Rule 5-1 and 5-2 Exposure Draft, February.

43. Park, C. H. (2003). In other (people's) words: plagiarism by university students- literature and lessons. Assessment \& Evaluations in Higher Education, 28(5), 471-488.

44. Prophet Mohammad (saw). Book (Bukhari, Muslim)

45. Prophet Mohammad (saw). Book (Tirmidhi)

46. Pickard, J. (2005). Using research into staff and student attitudes to plagiarism to change institutional culture. Paper presented at the Plagiarism: Prevention, Practice \& Policy Conference, Newcastle upon Tyne, 163-172.

47. Paulhus, D. L., Nathanson, C., \& Williams, K. M. (2005). A new look at the link between cognitive ability and exam cheating. In B. D. Zumbo (Ed.), Developments in the theories and applications of measurement, evaluation, and research methodologies across disciplines. Vancouver: University of British Columbia Press.

48. Quran: Surah Al Imran, verse:110

49. Raguz, I. V., \& Matic, M. (2015). Business students' attitudes towards business ethics: Evidence from Croatian Universities. UDC 005.1:17<(497.5)

50. Ryan, T. G., \& Bisson, J. (2011). Can ethics be taught? International Journal of Business and Social Science, 2(12), 44-52.

51. Rettinger D., A., \& Yair Kramer, K (2009). Situational and Personal Causes of Student Cheating, Res High Educ, 50, 293-313 DOI 10.1007/s11162-008-9116-5

52. Shafer, W. E., Lee, G. M., \& Fukukawa, K. (2007). Values and the perceived importance of ethics and social responsibility: the U.S. versus China. Journal of Business Ethics, 70(3), 265-284.

53. Sedmak, S., \& Nastav, B. (2010). Perception of Ethical Behaviour among Business Studies Students.' Social Responsibility, Professional Ethics, and Management. Proceedings of the 11th International Conference 2010 Ankara, Turkey, 2427 November 2010, 1175-1189.

54. Sauser, W. Jr. (2005). Ethics in business: answering the call. Journal of Business Ethics, 58, 345- 357.

55. Saini, S. (2012) Academic Ethics at the Undergraduate Level: Case Study from the
Formative Years of the Institute. I Acad Ethics, 11:35-44, DOI 10.1007/s10805-012-9169-0

56. Siegfried, R. M.: 2004, 'Student Attitudes on Software Piracy and Related Issues of Computer Ethics', Ethics and Information Technology, 6(4), 215-222.

57. Sparks, J. R., and Pan, Y. (2010). Ethical judgments in business ethics research: Definition and research agenda. Journal of Business Ethics, 91, $405-418$.

58. Stephens, J. M., Young, M. F., \& Calabrese, T. (2007). Does moral judgment go offline when students are online? A comparative analysis of undergraduates' beliefs and behaviors related to conventional and digital cheating.

59. Saunders, M. N. (2011). Research Methods for Business Students, (5th Ed.) Pearson Education India.

60. Seuring, S., and M. Müller. (2008). "From a Literature Review to a Conceptual Framework for Sustainable Supply Chain Management." Journal of Cleaner Production 16 (15): 1699-1710.

61. Selwyn, N. (2008). Not necessarily a bad thing: a study of online plagiarism amongst undergraduate students. Assessment \& Evaluation in Higher Education, 33(5), 465-479. doi:10.1080/026029307 01563104.

62. Sileo, J. M., \& Sileo, T. W. (2008). Academic dishonesty and online classes: A rural education perspective. Rural Special Education Quarterly, 27(1), 55-60. Retrieved from http://search. ebscohost.com/login.aspx?direct $=$ true \& $\mathrm{db}=\mathrm{aph} \& A$ $\mathrm{N}=32000995 \&$ site $=$ ehost-live.

63. Transparency International Bangladesh (TIB), Annual report - 2020 .

64. Tranfield, D., D. Denyer, \& P. Smart. (2003). "Towards a Methodology for Developing EvidenceInformed Management Knowledge by Means of Systematic Review." British Journal of Management 14 (3): 207-222.

65. Tseng, M.-L., M. S. Islam, N. Karia, F. A. Fauzi, and S. Afrin. (2019). A Literature Review on Green Supply Chain Management: Trends and Future Challenges. Resources, Conservation and Recycling, 141: 145-162.

66. Tian, X., Y. Geng, J. Sarkis, \& S. Zhong. (2018). Trends and Features of Embodied Flows Associated with International Trade Based on Bibliometric Analysis. Resources, Conservation and Recycling, 131: 148-157.

67. University Grants Commission of Bangladesh (2006). Strategic Plan for Higher Education in Bangladesh: 2006-2026, Dhaka.

68. University Grants Commission of Bangladesh (2005). Annual Report-2005.

69. University Grants Commission of Bangladesh (2015). Annual Report-2015. 
70. Weisul, K., \& Merritt, J. (2002). You mean cheating is wrong? Business Week December, 9, 8.

71. Whitley, B. E., \& Keith-Spiegel, P. (2002). Academic dishonesty: An educator's guide. Mahwah, NJ: Lawrence Erlbaum Associates.

72. Weygandt, J. J., Kieso, D. R., \& Kimmel, P. D. (2003). Financial Accounting (4th ed.). USA: Wiley

73. West, T., Ravenscroft, S. P., \& Shrader, C. B. (2004). Cheating and moral judgment in the college classroom: a natural experiment. Journal of Business Ethics, 54(2), 173-183.

74. Williams, S., Tanner, M., Beard, J., \& Chacko, J. (2014). Academic Misconduct among Business Students: A Comparison of the US and UAE. Springer Science+Business Media Dordrecht 2014, $J$ Acad Ethics, 12:65-73 DOI 10.1007/s10805-0139200-0

75. Walker, J. (2010). Measuring plagiarism: researching what students do, not what they say they do. Studies in Higher Education, 35(1), 41-59. doi:10.1080/03075070902912994.

76. Yardley, J., Rodriguez, M. D., Bates, S. C., \& Nelson, J. (2009). True confessions?: Alumni's retrospective reports on undergraduate cheating behaviors. Ethics \& Behavior, 19(1), 1-14.doi:10.1 080/10508420802487096.

77. Yadav, M. S. (2010). The decline of conceptual articles and implications for knowledge development. Journal of Marketing, 74(1), 1-19.

78. Zopiatis, A. A., \& Krambia-Kapardis, M. (2008). Ethical behavior of Tertiary Education Students in Cyprus. Journal of Business Ethics 81: 647663. 